Article

\title{
Synthesis of New 2-(2'-Hydroxyaryl)benzotriazoles and Evaluation of Their Photochemical Behavior as Potential UV-Filters
}

\author{
Renata Farkas ${ }^{1}$, Virginie Lhiaubet-Vallet ${ }^{2}$, Jordi Corbera ${ }^{3}$, Mercedesz Törincsi ${ }^{1}$, \\ Olga Gorchs ${ }^{4}$, Carles Trullas ${ }^{4}$, Oscar Jiménez ${ }^{4}$, Miguel A. Miranda ${ }^{2, *}$ and Lajos Novak ${ }^{1, *}$ \\ 1 Research Group for Alkaloid Chemistry, Department of Organic Chemistry and Technology, \\ Budapest University of Technology and Economics, Hungarian Academy of Sciences. Gellért tér 4, \\ 1111 Budapest, Hungary \\ 2 Instituto de Tecnología Química UPV-CSIC, Universidad Politécnica de Valencia, Avda de Los \\ Naranjos s/n, 46022 Valencia, Spain \\ 3 ESTEVE. Avda. Mare de Déu de Montserrat, 221, 08041 Barcelona, Spain \\ 4 ISDIN. Provençals 33, 08019 Barcelona, Spain \\ * Authors to whom correspondence should be addressed; E-Mail: lnovak@mail.bme.hu (L.N.); \\ Tel.: +36 14632207; Fax: +36 14633297; E-Mail: mmiranda@qim.upv.es (M.A.M.); \\ Tel.: + 34 963877807; Fax: + 34963877809 .
}

Received: 29 June 2010; in revised form: 23 August 2010 / Accepted: 1 September 2010 /

Published: 3 September 2010

\begin{abstract}
Two new 2-(2'-hydroxyaryl)benzotriazole derivatives were synthesized and studied by photophysical and photochemical techniques in order to assess their ability to act as UV-filters. The absorption and emission properties of both compounds were determined in solvents of different polarity. In non polar solvent, a photoinduced excited state intramolecular proton transfer was established leading to efficient non radiative dissipation of UV-energy. In addition, the compounds considered were photostable under irradiation with simulated sunlight.
\end{abstract}

Keywords: benzotriazoles; benzenediol; UV-filters; UV-stabilizers 


\section{Introduction}

A number of molecules with intramolecular H-bonds are commercially employed as UV-stabilizers, due to their strong UV-absorption bands, short excited state lifetimes, and high photostability. An essential property of UV absorbers is that they possess a mechanism for rapid dissipation of the absorbed radiation via an appropriate intramolecular rearrangement. Among the best known chromophores of this type are 2-(2'-hydroxyphenyl)benzotriazole derivatives, and especially 2-(2'hydroxy-5'-methylphenyl)benzotriazole (TIN, trade name Tinuvin P) [1], widely used as UV-stabilizer, or its silylated analog (trade name Mexoryl XL) used as a UV filter [2,3]. The photostability of these compounds has been attributed to photoinduced excited state intramolecular proton transfer (ESIPT) leading to an efficient (more than 99\%) and rapid non-radiative dissipation of the harmful UV-energy.

From a mechanistic point of view, the relaxation mechanism involves ESIPT from the $\mathrm{S}_{1}$ state occurring in the femtosecond timescale [4,5], then radiative decay of the excited keto tautomer (fluorescence emission with a large Stokes shift) is followed by back proton transfer, causing a return to the ground state phenol (or enol) form (Scheme 1).

Scheme 1. Non-radiative dissipation of UV-energy by photoinduced excited state intramolecular proton transfer.

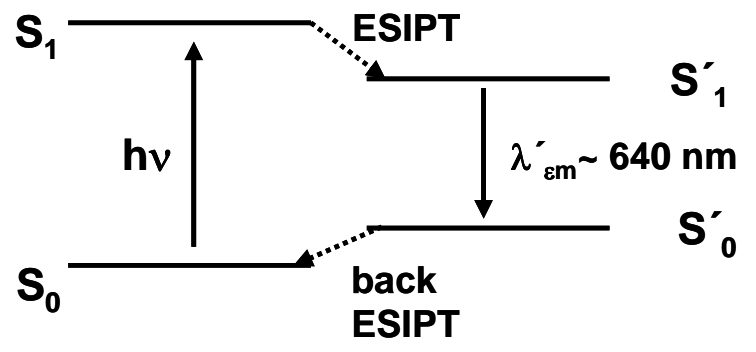

In this context, the existence of an intramolecular hydrogen bond is of fundamental importance for photostability [6]. In the case of TIN, blue fluorescence of the non proton transferred form $\mathrm{S}_{1}\left(\lambda_{\max } c a\right.$. $390 \mathrm{~nm}$ ) and phosphorescence at low temperature have been observed in polar solvents [7-9], where the intramolecular hydrogen bond is broken in favor of the intermolecular interactions with the solvent, or when the molecule is distorted or held a non planar conformation [10,11]. In addition, a short-lived triplet state has been detected for TIN in DMSO by laser flash photolysis experiments performed at room temperature [12]. By contrast, in non polar solvents blue emission is not observed due to the strong intramolecular hydrogen bond, which favors formation of the $\mathrm{S}_{1}{ }^{\prime}$ excited state whose long wavelength emission is detected at low temperature [7,13]. With this background, the aim of the present study is to synthesize two derivatives of 2-(2'-hydroxyphenyl)benzotriazole ((Figure 1) and to study their photophysical and photochemical properties in order to evaluate their ability to act as new UV-filters. 
Figure 1. Compounds prepared and investigated.<smiles>CO[Si](C)(C)CC(C)Cc1cc(-c2ccccc2)cc(-n2nc3ccccc3n2)c1O</smiles><smiles>CCOc1cc(O)c(-n2nc3ccccc3n2)c(O)c1</smiles>

\section{Results and Discussion}

\subsection{Synthetic study}

Compound 1 was synthesized by a stepwise synthetic protocol shown in Scheme 2. Namely, compound 3 [14] was heated with methallyl chloride in the presence of $\mathrm{K}_{2} \mathrm{CO}_{3}$ and $\mathrm{KI}$ to afford ether 4. Thermal rearrangement of the latter in $N, N$-diethylaniline afforded intermediate 5 , which was then silylated using heptamethyltrisiloxane and Karlstedt catalyst $[15,16]$ to give the wanted product $\mathbf{1}$ in good yield.

Scheme 2. Synthesis of 1.
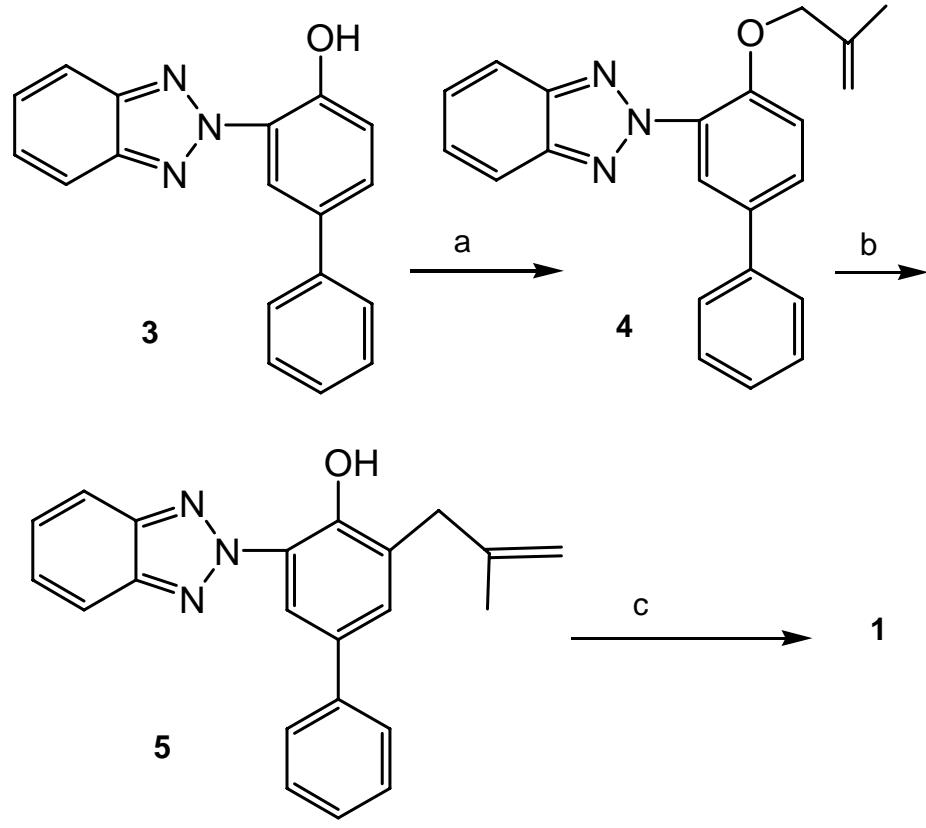

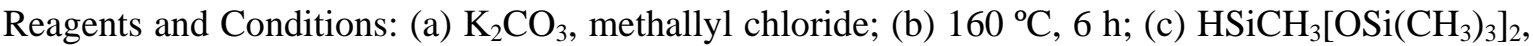
Karstedt catalyst. 
Compound 2 was prepared according to Scheme 3. Commercially available $o$-nitroaniline was treated with a mixture of $\mathrm{NaNO}_{2}$ and $\mathrm{HCl}$, and the formed diazo compound 7 was coupled with dibenzyloxyphenol (8) [17]. This reaction gave a 3:1 mixture of isomers $\mathbf{9}$ and 10. Without separation the mixture was treated with formamidinesulfinic acid and the formed benzotriazoles $\mathbf{1 1}$ and $\mathbf{1 2}$ were separated by fractional crystallization and column chromatography. Compound $\mathbf{1 1}$ was subsequently reacted with $\mathrm{NaH}$ and chloropropyl-triethoxy-silane to yield compound 13, from which the benzyl protective groups were removed by heating with $\mathrm{Pd} / \mathrm{C}$ and cyclohexene. Product 2 was purified by column chromatography.

Scheme 3. Synthesis of 2.

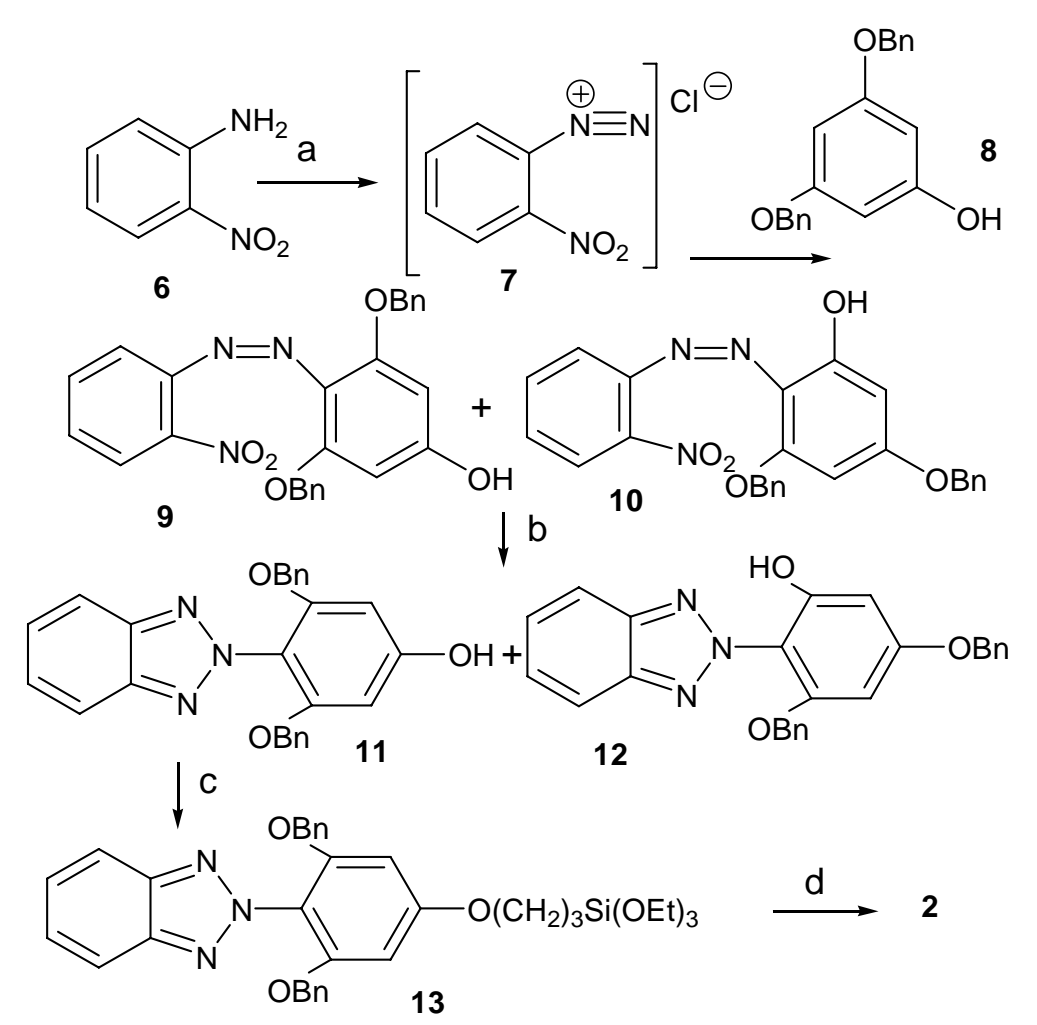

Reagents: (a) $\mathrm{NaNO}_{2}, \mathrm{HCl}$; (b) formamidinesulfinic acid; (c) $\mathrm{NaH}$, chloropropyl-triethoxy-silane;

(d) $\mathrm{Pd} / \mathrm{C}$, cyclohexene.

\subsection{Absorption spectra}

The absorption spectra of compound 2 in ethanol showed two maxima, $\lambda_{1}$ at $c a .285 \mathrm{~nm}$ and $\lambda_{2}$ at ca. $350 \mathrm{~nm}$. As shown in Figure 1, their relative intensity was dependent on the solvent. For example, in hexane, diethyl ether or acetonitrile, only the UVA absorption band was observed, while in DMSO or DMF the band at $285 \mathrm{~nm}$ was predominating. These results are consistent with the data reported for the chelated and non chelated forms of TIN and other 2'-hydroxybenzotriazole derivatives [7,9]. Indeed, in solvents with low hydrogen bonding capability, the intramolecular hydrogen bond is intact and only absorption of the chelated form is observed; by contrast, in solvents where the intramolecular hydrogen bond is partially disrupted, absorption of the two forms is clearly visible. 
Figure 2. Absorption spectra of 2 in different solvents (concentration ca. $10^{-5} \mathrm{M}$ ).

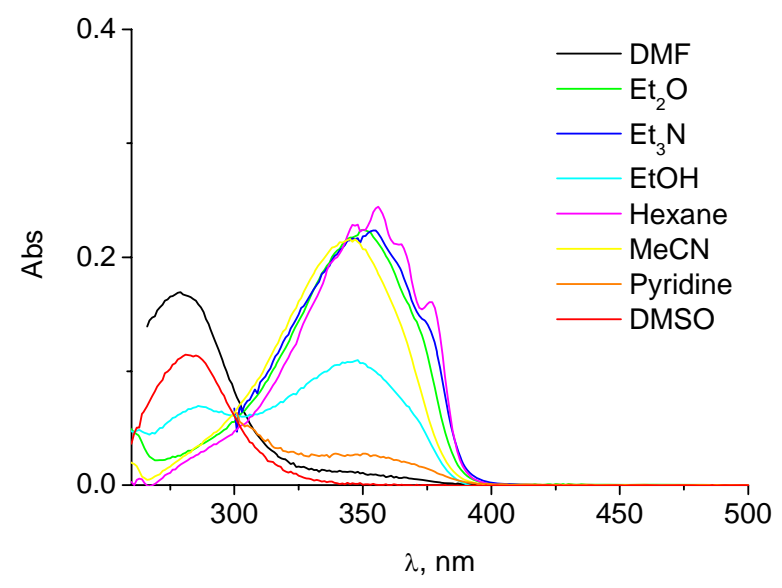

In the case of compound 1, two absorption maxima, $\lambda_{1}$ at $c a .300 \mathrm{~nm}$ and $\lambda_{2}$ at $c a .350 \mathrm{~nm}$ were also observed; however, by contrast with compound 2 the solvent-dependent spectral changes were not clearcut (Figure 3). This is probably attributable to overlapping of the absorption bands of the non chelated form and the hydroxybiphenyl chromophore.

Figure 3. Absorption spectra of 1 in different solvents (concentration ca. $3 \times 10^{-5} \mathrm{M}$ ).

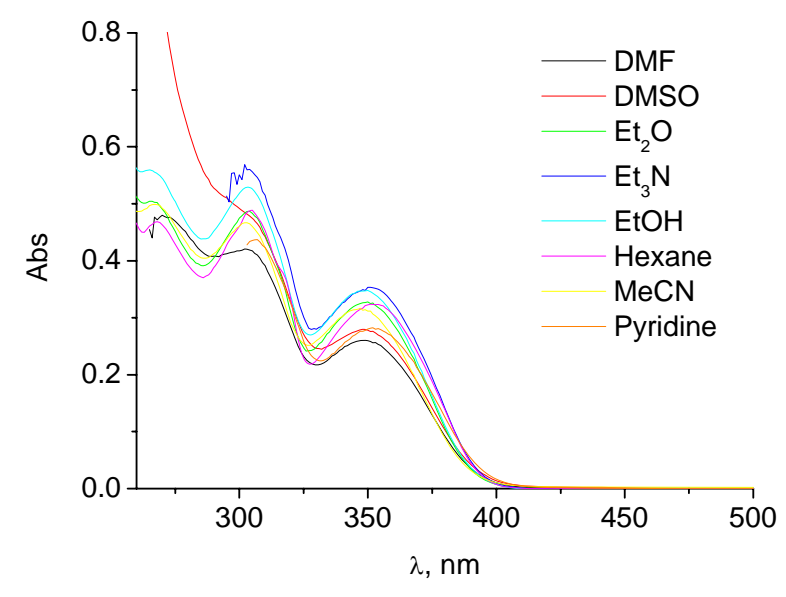

\subsection{Fluorescence emission}

For compound 2, no emission was observed at room temperature in hexane (data not shown) after excitation at $350 \mathrm{~nm}$. This is in agreement with previous results reporting only a weak red fluorescence at low temperature for TIN and other 2'-hydroxybenzotriazole derivatives [7]. Conversely, in polar solvents after excitation at $280 \mathrm{~nm}$, a blue fluorescence appeared at $410 \mathrm{~nm}$ (Figures 4a and 4b). The corresponding excitation spectra nearly matched the short wavelength absorption band. Thus, taking into account the literature data and the Stokes shift $\left(9,800\right.$ and $10,400 \mathrm{~cm}^{-1}$ in ethanol and DMSO, respectively), this emission was attributed to the non chelated form of compound 2. 
Figure 4. Fluorescence emission $\left(\lambda_{\text {exc }}=280 \mathrm{~nm}\right)$ spectra of 2 in DMSO (a) and in ethanol (b). Inset: corresponding excitation spectra.

(a)

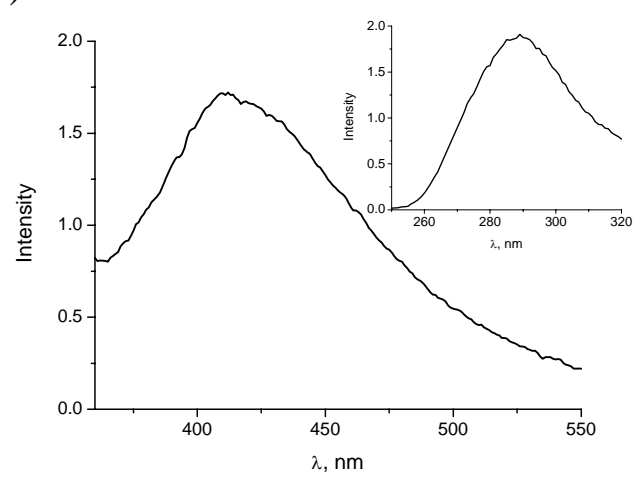

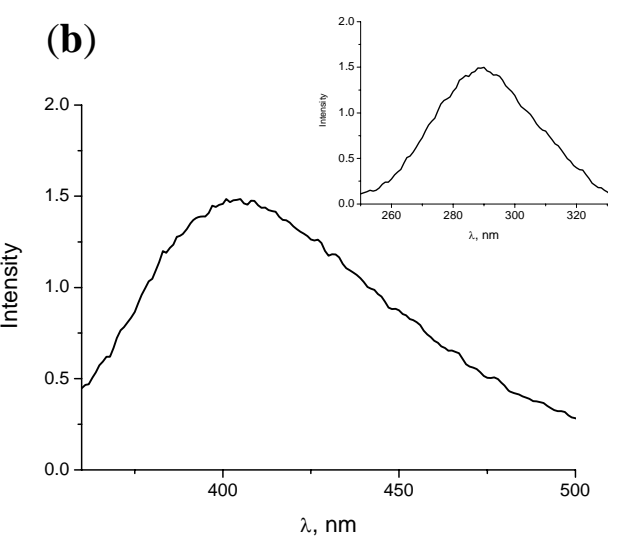

Figure 5. Fluorescence emission spectra of 1 in hexane at $\lambda_{\text {exc }}=300 \mathrm{~nm}$ (a) and in DMSO $\lambda_{\text {exc }}=280 \mathrm{~nm}$ (b) and $340 \mathrm{~nm}$ (c). Inset: corresponding excitation spectra.

(a)

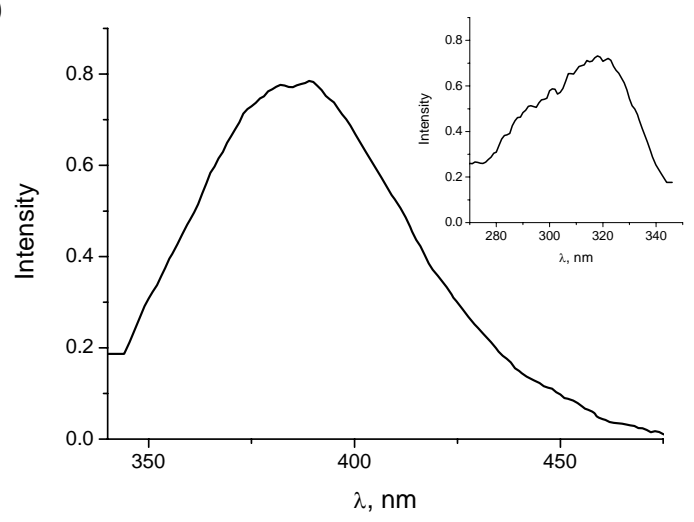

(b)

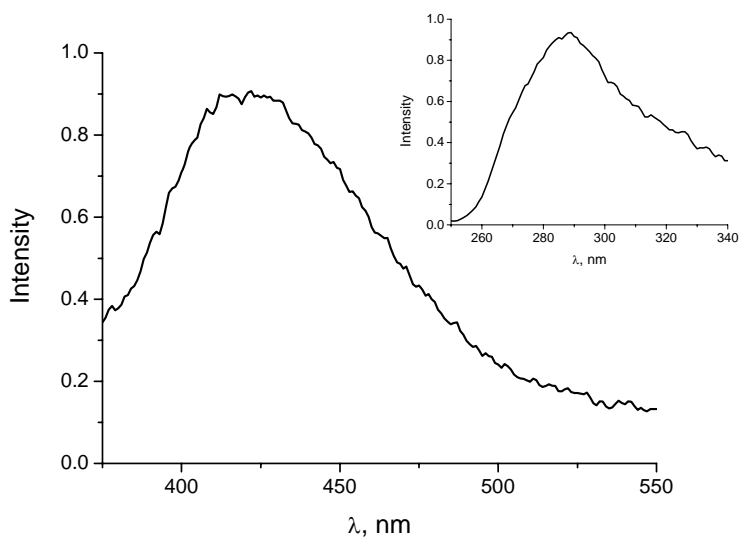

(c)

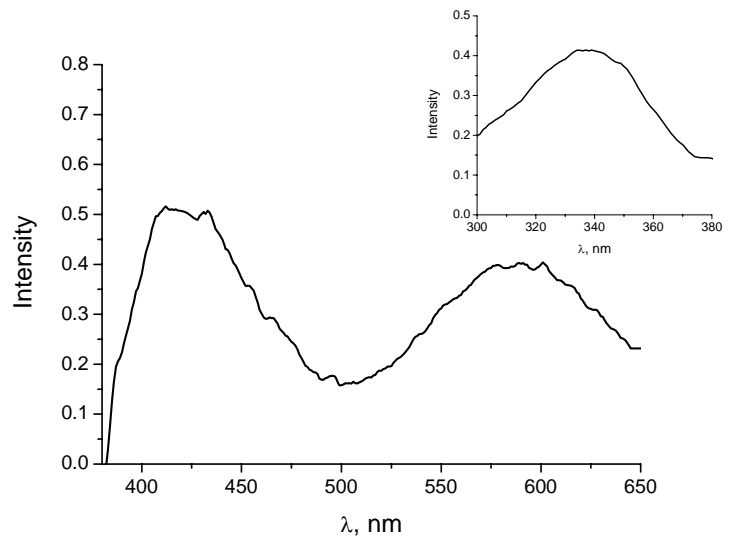

In the case of the biphenyl derivative 1, an emission band centred at $390 \mathrm{~nm}$ was detected in hexane after excitation at $300 \mathrm{~nm}$; accordingly, the corresponding excitation spectrum exhibited a maximum at ca. $300 \mathrm{~nm}$ (Figure 5a). By contrast, no signal was observed after excitation at $350 \mathrm{~nm}$. In ethanol, no significant fluorescence was detected after excitation at either of the two wavelengths. In the case of DMSO, a band centred at $410 \mathrm{~nm}$ was observed after excitation at $280 \mathrm{~nm}$ (Figure 5b), after excitation 
at $340 \mathrm{~nm}$ this emission was still observed and, remarkably, a new emission band at $590 \mathrm{~nm}$ appeared (Figure 5c). The excitation spectrum of the latter agreed well with the red shifted fluorescence of the chelated form previously described in the literature [7].

\subsection{Photostability}

In order to assess the photostability of compounds 1 and 2, irradiations of $2.7 \times 10^{-5} \mathrm{M}$ solutions were performed in different solvents and their degradation was followed by UV-Vis spectroscopy. After 2 hours of irradiation, the UVA-band was decreased by less than 5\% (Figure 6). Thus, these results are similar to those previously reported for TIN and reflect the conservation of the UVA absorption capability of both compounds, an important property of UV-filters.

Figure 6. UVA-absorption changes after simulated solar irradiation (up to $2 \mathrm{~h}$ ) of compound $\mathbf{2}$ in hexane (a) and ethanol (b). Same experiments with compound $\mathbf{1}$ in hexane (c) and ethanol (d).
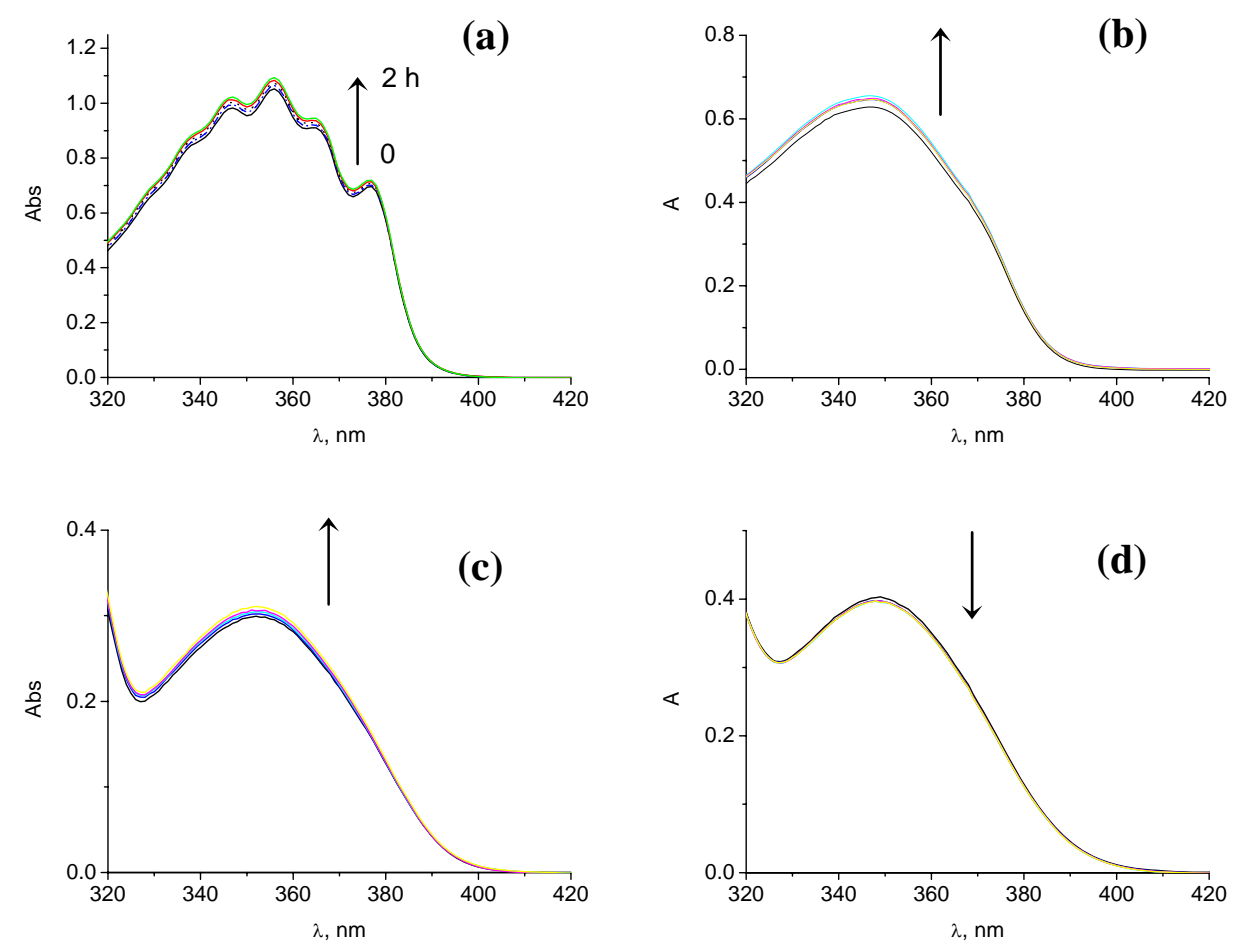

\section{Experimental}

\subsection{General}

Solvents for synthesis were used as received from commercial suppliers, and no further attempts were made to purify or dry them. Melting points were determined on a Büchi apparatus and are uncorrected. IR spectra were recorded on Bruker Alpha FT Spectrophotometer. ${ }^{1} \mathrm{H}-\mathrm{NMR}$ and ${ }^{13} \mathrm{C}$ NMR spectra were obtained on a Bruker DRX-500 spectrometer operating at $500 \mathrm{MHz}$ and $125 \mathrm{MHz}$, respectively. All NMR spectra are reported in ppm relative to TMS. MS spectra were conducted on 
Agilent 6140 quadrupole LC/MS instrument. Merck precoated silica gel $60 \mathrm{~F}_{254}$ plates were used for TLC and Kieselgel 60 for column chromatography.

\subsection{Synthesis}

2-\{4-[(-2-Methyl-2-propen-1-yl)oxy]-3-biphenylyl\}-2H-1,2,3-benzotriazole (4). Under an argon atmosphere, a stirred mixture of 3 (5.0 g, $17 \mathrm{mmol})$, methallyl chloride (2.7 g, $30 \mathrm{mmol})$, KI (5.8 g, $35 \mathrm{mmol})$, and $\mathrm{K}_{2} \mathrm{CO}_{3}(2.4 \mathrm{~g}, 17 \mathrm{mmol})$ in butan-2-one $(100 \mathrm{~mL})$ was refluxed for $12 \mathrm{~h}$. After cooling the precipitate was removed by filtration, the filtrate was concentrated in vacuo, and the resulting solid was subjected to column chromatography to give a white-yellow solid. Yield: 65\% (3.77 g). m.p. 94-96 ${ }^{\circ}$ C. $R_{f}=0.6$ (hexane-acetone 5:2). IR (KBr): 1620, 1540, 1500, 1360, 1300, 1280, $1260 \mathrm{~cm}^{-1}$. ${ }^{1} \mathrm{H}-\mathrm{NMR}\left(\mathrm{CDCl}_{3}\right): 1.71$ (s, 3H, $\left.\mathrm{CH}_{3}\right), 4.55$ (s, 2H, C ${ }_{1}$,-H), 4.90 (s, 1H, C ${ }_{3}$,-H), $5.00\left(\mathrm{~s}, 1 \mathrm{H}, \mathrm{C}_{3}{ }^{\prime-H}\right)$, 7.19 (d, $\left.J=8.7 \mathrm{~Hz}, 1 \mathrm{H}, \mathrm{C}_{5},-\mathrm{H}\right), 7.33$ (t, $\left.J=8.5 \mathrm{~Hz}, 1 \mathrm{H}, \mathrm{C}_{10},-\mathrm{H}\right), 7.43$ (m, 2H, C9,-H and $\left.\mathrm{C}_{11},-\mathrm{H}\right), 7.45$ (m, 2H, $\mathrm{C}_{5}-\mathrm{H}$ and $\mathrm{C}_{6}-\mathrm{H}$ ), 7.60 (d, $J=8.5 \mathrm{~Hz}, 2 \mathrm{H}, \mathrm{C}_{8},-\mathrm{H}$ and $\mathrm{C}_{12},-\mathrm{H}$ ), 7.70 (dd, $J=8.7$ and $2.3 \mathrm{~Hz}, 1 \mathrm{H}$, $\left.\mathrm{C}_{6},-\mathrm{H}\right), 7.94\left(\mathrm{~d}, J=2.3 \mathrm{~Hz}, 1 \mathrm{H}, \mathrm{C}_{2},-\mathrm{H}\right), 7.98\left(\mathrm{~m}, 2 \mathrm{H}, \mathrm{C}_{4}-\mathrm{H}\right.$ and $\left.\mathrm{C}_{7}-\mathrm{H}\right) .{ }^{13} \mathrm{C}-\mathrm{NMR}\left(\mathrm{CDCl}_{3}\right): 19.17$ ( $\mathrm{CH}_{3}$ ), 72.78 (C-1”), 112.90 (C-3”), 114.72 (C-5'), 118.44 (C-4 and C-7), 126.12 (C-2'), 126.82 (C-5, C-6, C-8', and C-12'), 127.37 (C-10'), 128.87 (C-9' and C-11'), 129.28 (C-6’), 130.91 (C-3’), 134.31 (C-1'), 139.33 (C-7'), 139.87 (C-2”), 144.85 (C-3a and C-7a), 152.00 (C-4'). Anal. Calcd for $\mathrm{C}_{22} \mathrm{H}_{19} \mathrm{~N}_{3} \mathrm{O}$ : C, 77.40; H, 5.61; N, 12.31. Found: C, 77.14; H, 5.72; N, 12.07.

3-(2H-1,2,3-Benzotriazol-2-yl)-5-(2-methyl-2-propen-1-yl)-4-biphenylol (5). A solution of ether 4 (10.2 g, $30 \mathrm{mmol})$ in $N, N$-diethylaniline $(50 \mathrm{~mL})$ was heated at reflux for $4 \mathrm{~h}$. After cooling, $\mathrm{HCl}$ (15\%, $50 \mathrm{~mL})$ was added and the resulting solution was extracted with $\mathrm{CH}_{2} \mathrm{Cl}_{2}(3 \times 50 \mathrm{~mL})$. The combined organic extracts were washed with water, evaporated in vacuo, and the residue was recrystallized from hexane. Yield: $87 \%$ (8.9 g, light yellow crystals). m.p. $115-117{ }^{\circ} \mathrm{C} . R f=0.8$ (hexane-acetone 5:2). IR (KBr): 3400, 3100, 1620, 1500, 1480, 1450, 1360, $1280 \mathrm{~cm}^{-1} .{ }^{1} \mathrm{H}-\mathrm{NMR}$ $\left(\mathrm{CDCl}_{3}\right): 1.84$ (s, 3H, $\left.\mathrm{CH}_{3}\right), 3.58$ (s, 2H, C ${ }_{1}$,-H), 4.80 (s, 1H, C $\left.{ }_{3},-\mathrm{H}\right), 4.89$ (s, 1H, C $\left.{ }_{3},-\mathrm{H}\right), 7.35$ (t, $\left.J=7.5 \mathrm{~Hz}, \mathrm{C}_{10}-\mathrm{H}\right), 7.46\left(\mathrm{~m}, 3 \mathrm{H}, \mathrm{C}_{6}-\mathrm{H}, \mathrm{C}_{9}-\mathrm{H}\right.$, and $\left.\mathrm{C}_{11}-\mathrm{H}\right), 7.49\left(\mathrm{~m}, 2 \mathrm{H}, \mathrm{C}_{5},-\mathrm{H}\right.$ and $\left.\mathrm{C}_{6},-\mathrm{H}\right), 7.67$ (d, $J=8.5 \mathrm{~Hz}, 2 \mathrm{H}, \mathrm{C}_{8}-\mathrm{H}$ and $\left.\mathrm{C}_{12}-\mathrm{H}\right), 7.94\left(\mathrm{~m}, 2 \mathrm{H}, \mathrm{C}_{4},-\mathrm{H}\right.$ and $\left.\mathrm{C}_{7}-\mathrm{H}\right), 8.56\left(\mathrm{~d}, J=2.3 \mathrm{~Hz}, 1 \mathrm{H}, \mathrm{C}_{2}-\mathrm{H}\right), 11.67$ (s, 1H, OH). ${ }^{13} \mathrm{C}-\mathrm{NMR}\left(\mathrm{CDCl}_{3}\right): 22.57\left(\mathrm{CH}_{3}\right), 38.07$ (C-2”), 111.92 (C-3”), 117.67 (C-4' and C-7’), 117.75 (C-2), 125.39 (C-3), 126.83 (C-8 and C-12), 127.14 (C-10), 127.74 (C-5' and C-6'), 128.81 (C9 and C-11), 129.91 (C-6), 130.10 (C-5), 132.67 (C-1), 139.96 (C-7), 142.82 (C-3a' and C-7a'), 144.25 (C-2”), 147.52 (C-4). Anal. Calcd for $\mathrm{C}_{22} \mathrm{H}_{19} \mathrm{~N}_{3} \mathrm{O}$ : C, 77.40; H, 5.61; N, 12.31. Found: C, 77.17; H, 5.82; N, 12.17.

3-(2H-1,2,3-Benzotriazol-2-yl)-5-(2-methyl-3-\{1,3,3,3-tetramethyl-1-[(trimethylsilyl)oxy]disiloxanyl\}propyl)-4-biphenylol (1). To a stirred solution of 5 (2.0 g, $6 \mathrm{mmol})$ in dry xylene $(40 \mathrm{~mL})$ was added 1,1,1,3,5,5,5-heptamethyltrisiloxane (2.5 mL, $2.2 \mathrm{~g}, 9 \mathrm{mmol}$ ) and Karlstedt catalyst (15 drops) and the resulting mixture was heated at $100{ }^{\circ} \mathrm{C}$ for $5 \mathrm{~h}$. After cooling, the solvent was evaporated in vacuo and the residue was purified by column chromatography to give compound 1. Yield: $72 \%$ (2.4 g), yellow oil. $R_{f}=0.63$ (hexane-acetone 5:02). IR (KBr): $3250(\mathrm{OH}), 1625,1500,1250,1090,1060 \mathrm{~cm}^{-1} .{ }^{1} \mathrm{H}-$ NMR ( $\mathrm{CDCl}_{3}$ ): 0.10 (s, 3H, $\left.\mathrm{CH}_{3}\right), 0.11$ (s, 9H, 3CH ), 0.12 (s, 9H, $\mathrm{CH}_{3}$ ), 0.56 (dd, $J=14.8$ and $9.2 \mathrm{~Hz}$, $\left.1 \mathrm{H}, \mathrm{C}_{3},-\mathrm{H}\right), 0.78$ (dd, $J=14.8$ and $\left.4.7 \mathrm{~Hz}, 1 \mathrm{H}, \mathrm{C}_{3},-\mathrm{H}\right), 1.05\left(\mathrm{~d}, J=6.6 \mathrm{~Hz}, 3 \mathrm{H}, \mathrm{CH}_{3}\right.$ ), 
2.23 (m, 1H, C ${ }_{2}$-H), 2.73 (dd, $J=13.2$ and $8.2 \mathrm{~Hz}, 1 \mathrm{H}, \mathrm{C}_{1}$ ”-H), 2.89 (dd, $J=13.2$ and $6.2 \mathrm{~Hz}, 1 \mathrm{H}, \mathrm{C}_{1}$ ”H), $7.38\left(\mathrm{t}, J=7.4 \mathrm{~Hz}, 1 \mathrm{H}, \mathrm{C}_{10}-\mathrm{H}\right), 7.49\left(\mathrm{~m}, 3 \mathrm{H}, \mathrm{C}_{6}-\mathrm{H}, \mathrm{C}_{9}-\mathrm{H}\right.$, and $\left.\mathrm{C}_{11}-\mathrm{H}\right), 7.52\left(\mathrm{~m}, 2 \mathrm{H}, \mathrm{C}_{5},-\mathrm{H}\right.$ and $\mathrm{C}_{6},-$ $\mathrm{H}), 7.71\left(\mathrm{~d}, J=7.5 \mathrm{~Hz}, 2 \mathrm{H}, \mathrm{C}_{8}-\mathrm{H}\right.$ and $\left.\mathrm{C}_{12}-\mathrm{H}\right), 7.98\left(\mathrm{~m}, 2 \mathrm{H}, \mathrm{C}_{4},-\mathrm{H}\right.$ and $\left.\mathrm{C}_{7},-\mathrm{H}\right), 8.57(\mathrm{~d}, J=3.3 \mathrm{~Hz}, 1 \mathrm{H}$, $\left.\mathrm{C}_{2}-\mathrm{H}\right), 11.60$ (s, $\left.1 \mathrm{H}, \mathrm{OH}\right) .{ }^{13} \mathrm{C}-\mathrm{NMR}\left(\mathrm{CDCl}_{3}\right): 0.85\left(\mathrm{CH}_{3}\right), 1.87\left(6 \mathrm{CH}_{3}\right), 22.48\left(\mathrm{CH}_{3}\right), 26.18(\mathrm{C}-3$ ”), 29.31 (C-2”), 41.27 (C-1”), 117.39 (C-2), 117.66 (C-4' and C-7'), 125.34 (C-3), 126.83 (C-8 and C12), 127.03 (C-10), 127.64 (C-5' and C-6’), 128.77 (C-9 and C-11), 130.56 (C-6), 132.14 (C-5), 132.34 (C-1), 140.14 (C-7), 142.81 (C-3a' and C-7a'), 147.66 (C-4). MS (m/z): 563 (M+, 5\%), 474 [M+- $\left.\left(\mathrm{CH}_{3}\right)_{3} \mathrm{SiO}, 46\right], 101$ (100). Anal. Calcd for $\mathrm{C}_{29} \mathrm{H}_{41} \mathrm{~N}_{3} \mathrm{O}_{3} \mathrm{Si}_{3}$ : C, 61.77; H, 7.33; N, 7.45. Found: C, 61.70; H, 7.52; N, 7.67.

4-(2H-1,2,3-Benzotriazol-2-yl)-3,5-bis(benzyloxy)phenol (11). To a cold $\left(0-5{ }^{\circ} \mathrm{C}\right)$ suspension of 2nitrobenzeneamine (6, $27.62 \mathrm{~g}, 0.2 \mathrm{~mol})$ in concentrated $\mathrm{HCl} 100 \mathrm{~mL})$, crashed ice $(100 \mathrm{~g})$ and water $(100 \mathrm{~mL})$, was added dropwise $5 \mathrm{~N}$ solution of $\mathrm{NaNO}_{2}(41 \mathrm{~mL})$. The resulting mixture was stirred at $5{ }^{\circ} \mathrm{C}$ for $1 \mathrm{~h}$ and then filtered. This solution of 7 was then added dropwise to a stirred solution of 3,5bis(benzyloxy)phenol (8, $61.3 \mathrm{~g}, 0.2 \mathrm{~mol})$ in methanol $(600 \mathrm{~mL})$. Stirring was continued at room temperature for $2 \mathrm{~h}$ and the precipitated red crystalline compound was collected by filtration to give a 2:1 mixture of isomeric azo compounds 9 and 10. Yield: 88\% (80.77 g). m.p. $171-180{ }^{\circ} \mathrm{C} . R_{f}=0.52$ and 0.88 (toluene-MeOH 9:1). To a boiling suspension of the above mixture of azo-compounds (45.5 g, $0.1 \mathrm{~mol})$ in a mixture of EtOH $(250 \mathrm{~mL})$ and $4 \mathrm{~N} \mathrm{NaOH}(250 \mathrm{~mL})$ was added formamidinesulfinic acid (23.65 g, $0.22 \mathrm{~mol}$ ) during $0.5 \mathrm{~h}$. The resultant mixture was heated with stirring for $1 \mathrm{~h}$, cooled to room temperature, and then poured into a mixture of ice and water (700 g). The resulting mixture was acidified with concentrated $\mathrm{HCl}(80 \mathrm{~mL})$ and extracted with EtOAc. The organic layer was successively washed with water and brine, and then dried $\left(\mathrm{MgSO}_{4}\right)$. Evaporation of the solvent in vacuo afforded a red oil (42 g), which was then treated with a mixture of hexane and EtOAc (60 mL, each). The precipitated crystalline compounds were collected by filtration and washed with hexane-acetone (1:1) to give compound 11. Yield: $28 \%\left(12.64\right.$ g). m.p. $147-152{ }^{\circ} \mathrm{C} . R_{f}=0.38$ (toluene-MeOH 9:1) and 0.26 (hexane-EtOAc 2:1). ${ }^{1} \mathrm{H}-\mathrm{NMR}\left(\mathrm{CDCl}_{3}\right): 4.73$ (s, 4H, 2OCH ), 6.11 (s, $2 \mathrm{H}, \mathrm{C}_{2}-\mathrm{H}$ and $\left.\mathrm{C}_{6}-\mathrm{H}\right), 6.98\left(\mathrm{~m}, 4 \mathrm{H}, 2 \mathrm{C}_{2},-\mathrm{H}\right.$ and $\left.2 \mathrm{C}_{6},-\mathrm{H}\right), 7.07\left(\mathrm{~m}, 2 \mathrm{H}, 2 \mathrm{C}_{4},-\mathrm{H}\right), 7.10\left(\mathrm{~m}, 4 \mathrm{H}, 2 \mathrm{C}_{3},-\mathrm{H}\right.$ and 2C $\mathrm{C}_{5},-\mathrm{H}$ ), 7.43 (dd, $J=6.7$ and $3 \mathrm{~Hz}, 2 \mathrm{H}, \mathrm{C}_{5},-\mathrm{H}$ and $\mathrm{C}_{6},-\mathrm{H}$ ), 7.95 (dd, $J=6.7$ and $3 \mathrm{~Hz}, 1 \mathrm{H}, \mathrm{C}_{4},-\mathrm{H}$ and $\left.\mathrm{C}_{7},-\mathrm{H}\right), 8.62$ (s, $\left.1 \mathrm{H}, \mathrm{OH}\right) .{ }^{13} \mathrm{C}-\mathrm{NMR}\left(\mathrm{CDCl}_{3}\right)$ : $70.31\left(\mathrm{OCH}_{2}\right), 94.55$ (C-2), 113.03 (C-4), 118.23 (C-4' and C-7'), 126.61 (C-2” and C-6”), 126.88 (C-5' and C-6’), 127.65 (C-4”), 128.27 (C-3” and C-5”), 136.01 (C-1”), 144.37 (C-3a' and C-7a'), 156.00 (C-3 and C-5), 159.99 (C-1). Anal. Calcd for $\mathrm{C}_{26} \mathrm{H}_{21} \mathrm{~N}_{3} \mathrm{O}_{3}$ : C, 73.74; H, 5.00; N, 9.92. Found: C, 73.47; H, 5.22; N, 9.67.

The isomer - 2-(2H-1,2,3-benzotriazol-2-yl)-3,5-bis(benzyloxy)phenol (12) - was ISOLATED by column chromatography From the mother liquor. Yield: $12 \%\left(5.4\right.$ g). m.p. $71-78{ }^{\circ} \mathrm{C} . R_{f}=0.73$ (toluene-MeOH 9:1) and 0.48 (hexane-EtOAc 2:1). ${ }^{1} \mathrm{H}-\mathrm{NMR}\left(\mathrm{CDCl}_{3}\right)$ : 5.04 (s, 2H, $\mathrm{OCH}_{2}$ ), 5.16 (s, $2 \mathrm{H}, \mathrm{OCH}_{2}$ ), 6.38 (d, $\left.J=2.4 \mathrm{~Hz}, 1 \mathrm{H}, \mathrm{C}_{4}-\mathrm{H}\right), 6.41$ (d, $\left.J=2.4 \mathrm{~Hz}, 1 \mathrm{H}, \mathrm{C}_{6}-\mathrm{H}\right), 7.25$ (t, $J=7 \mathrm{~Hz}, 1 \mathrm{H}, \mathrm{C}_{4}$,-

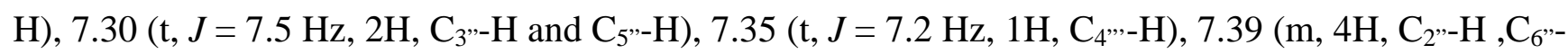
$\mathrm{H}, \mathrm{C}_{3},,-\mathrm{H}$ and $\left.\mathrm{C}_{5},-\mathrm{H}\right), 7.41\left(\mathrm{~m}, 2 \mathrm{H}, \mathrm{C}_{2},{ }^{\prime}, \mathrm{H}\right.$ and $\left.\mathrm{C}_{6},{ }^{\prime}-\mathrm{H}\right), 7.45$ (dd, $J=6.5 \mathrm{~Hz}, 2 \mathrm{H}, \mathrm{C}_{5},-\mathrm{H}$ and $\left.\mathrm{C}_{6},-\mathrm{H}\right)$, 7.94 (dd, $J=6.5 \mathrm{~Hz}, 2 \mathrm{H}, \mathrm{C}_{4},-\mathrm{H}$ and $\left.\mathrm{C}_{7},-\mathrm{H}\right), 9.36$ (br. s, $\left.1 \mathrm{H}, \mathrm{OH}\right) \cdot{ }^{13} \mathrm{C}-\mathrm{NMR}\left(\mathrm{CDCl}_{3}\right): 70.33\left(\mathrm{OCH}_{2}\right)$, $71.28\left(\mathrm{OCH}_{2}\right), 95.21$ (C-4), 95.81 (C-6), 112.50 (C-2), 117.87 (C-4' and C-7’), 126.86 (C-2” and C- 
6”), 127.23 (C-5' and C-6'), 127.62 (C-2”' and C-6”'), 127.77 (C-4”), 128.24 (C-4”'), 128.41 (C-3” and C-5”), 128.68 (C-3”' and C-5”'), 136.18 (C-1”'), 136.30 (C-1”), 143.64 (C-3a' and C-7a'), 152.80 (C-1), 153.67 (C-3), 160.62 (C-5). Anal. Calcd for $\mathrm{C}_{26} \mathrm{H}_{21} \mathrm{~N}_{3} \mathrm{O}_{3}$ : C, 73.74; H, 5.00; N, 9.92. Found: C, 73.49; H, 5.27; N, 9.72.

2-\{2,6-bis(Benzyloxy)-4-[3-(triethoxysilyl)propoxy]phenyl\}-2H-1,2,3-benzotriazole (13). To a stirred suspension of $\mathrm{NaH}$ (1.8 g, 60\% in mineral oil, $44 \mathrm{mmol}$ ) in dry DMF (80 mL) was added dropwise a solution of compound 11 (16.9 g, $40 \mathrm{mmol})$ in dry DMF (140 mL). After stirring for $45 \mathrm{~min}$ at room temperature chloropropyl-triethoxy-silane $(9.87 \mathrm{~g}, 40 \mathrm{mmol})$ and $\mathrm{KI}(6.43 \mathrm{~g}, 40 \mathrm{mmol})$ were added, and the resultant mixture was heated at $80^{\circ} \mathrm{C}$ for $8 \mathrm{~h}$. After cooling, the reaction mixture was poured into water $(200 \mathrm{~mL})$, extracted with ether $(3 \times 150 \mathrm{~mL})$, the organic layer was washed with brine, and then dried $\left(\mathrm{MgSO}_{4}\right)$. Evaporation of the solvent in vacuo afforded a reddish oil, which was purified by column chromatography (hexane-EtOAc 5:1 as eluent). Yield: $37 \%(9.13 \mathrm{~g})$, semi solid. $R_{f}=0.7$ (hexane-EtOAc 2:1). ${ }^{1} \mathrm{H}-\mathrm{NMR}\left(\mathrm{CDCl}_{3}\right): 0.79$ (m, 2H, $\left.\mathrm{CH}_{2}-\mathrm{Si}\right), 1.27$ (t, $\left.J=7 \mathrm{~Hz}, 9 \mathrm{H}, 3 \mathrm{CH}_{3}\right), 1.93$ (m, $2 \mathrm{H}, \mathrm{CH}_{2}$ ), 3.88 (q, $J=7 \mathrm{~Hz}, 6 \mathrm{H}, 3 \mathrm{OCH}_{2}$ ), 3.92 (t, $J=6.6 \mathrm{~Hz}, 2 \mathrm{H}, \mathrm{OCH}_{2}$ ), 5.07 (s, 4H, 2OCH $), 6.28$ (s, 2H, $\mathrm{C}_{3},-\mathrm{H}$ and $\left.\mathrm{C}_{5},-\mathrm{H}\right), 7.17$ (d, $J=7.5 \mathrm{~Hz}, 4 \mathrm{H}, \mathrm{C}_{2},-\mathrm{H}$ and $\left.\mathrm{C}_{6},-\mathrm{H}\right), 7.23\left(\mathrm{~m}, 6 \mathrm{H}, \mathrm{C}_{3},-\mathrm{H}, \mathrm{C}_{4},-\mathrm{H}\right.$, and $\mathrm{C}_{5}$,-H), 7.44 (dd, $J=6.6$ and $3 \mathrm{~Hz}, 2 \mathrm{H}, \mathrm{C}_{5}-\mathrm{H}$ and $\mathrm{C}_{6}-\mathrm{H}$ ), 8.1 (dd, $J=6.6$ and $3 \mathrm{~Hz}, 2 \mathrm{H}, \mathrm{C}_{4}-\mathrm{H}_{\text {and }} \mathrm{C}_{7^{-}}$ H). ${ }^{13} \mathrm{C}-\mathrm{NMR}\left(\mathrm{CDCl}_{3}\right)$ : 6.47 (C-Si), $18.30\left(\mathrm{CH}_{3}\right), 22.62$ (-C-Si), 58.43 (C-O),70.16 (C-O), 70.57 (CO), 93.38 (C-3' and C-5'), 114.53 (C-1'), 118.47 (C-4 and C-7), 126.29 (C-5 and C-6), 126.52 (C-2” and C-6”), 127.62 (C-4”), 128.32 (C-3” and C-5”), 136.19 (C-1”), 144.74 (C-3a and C-7a), 156.06 (C2' and C-6'), 161.65 (C-4'). Anal. Calcd for $\mathrm{C}_{35} \mathrm{H}_{41} \mathrm{~N}_{3} \mathrm{O}_{6} \mathrm{Si}$ : C, 66.96; H, 6.58; N, 6.69. Found: C, 67.09; H, 6.29; N, 6.47.

2-(2H-1,2,3-Benzotriazol-2-yl)-5-[3-(triethoxysilyl)propoxy]-1,3-benzenediol (2). A stirred mixture of compound 13 (2 g, $3.2 \mathrm{mmol}$ ), palladium catalyst (1 g, 10\% Pd on charcoal), and cyclohexene (64 mL, $52 \mathrm{~g}, 0.6 \mathrm{~mol})$ in EtOH $(80 \mathrm{~mL})$ was heated at reflux for $1.5 \mathrm{~h}$. After filtration, the solvent was evaporated in vacuo and the residue was purified by column chromatography. Yield: 76\% (1.08 g, light yellow crystals). m.p. 69-74 ${ }^{\circ} \mathrm{C} . R_{f}=0.27\left(\mathrm{CH}_{2} \mathrm{Cl}_{2}\right) .{ }^{1} \mathrm{H}-\mathrm{NMR}\left(\mathrm{CDCl}_{3}\right): 0.80$ (m, $\left.2 \mathrm{H}, \mathrm{CH}_{2}-\mathrm{Si}\right)$, 1.27 (t, $J=7 \mathrm{~Hz}, 9 \mathrm{H}, 3 \mathrm{CH}_{3}$ ), $1.95\left(\mathrm{~m}, 2 \mathrm{H}, \mathrm{CH}_{2}\right.$ ), 3.88 (q, $\left.J=7 \mathrm{~Hz}, 6 \mathrm{H}, 3 \mathrm{O}-\mathrm{CH}_{2}\right), 4.00$ (t, $J=6.6 \mathrm{~Hz}$, $\left.2 \mathrm{H}, \mathrm{CH}_{2}\right), 6.29\left(\mathrm{~s}, 2 \mathrm{H}, \mathrm{C}_{5}-\mathrm{H}\right.$ and $\left.\mathrm{C}_{6}-\mathrm{H}\right), 7.93\left(\mathrm{~m}, 2 \mathrm{H}, \mathrm{C}_{4}-\mathrm{H}\right.$ and $\left.\mathrm{C}_{7}-\mathrm{H}\right), 11.56(\mathrm{~s}, 2 \mathrm{H}, \mathrm{OH}) .{ }^{13} \mathrm{C}-\mathrm{NMR}$ $\left(\mathrm{CDCl}_{3}\right)$ : 6.45 (C-Si), $18.29\left(\mathrm{CH}_{3}\right), 22.64$ (C-2'’), 58.43 (C-O), 70.10 (C-1'’), 95.73 (C-6), 108.17 (C2), 116.62 (C-4' and C-7'), 127.87 (C-5' and C-6'), 140.18 (C-3a and C-7a), 152.07 (C-1 and C-3), 160.93 (C-5). MS (m/z): 447 (M+1, 8 \%), 283 [M+-HSi(OEt) $\left.)_{3}, 12\right], 256$ (17), 124 (100). Anal. Calcd for $\mathrm{C}_{21} \mathrm{H}_{29} \mathrm{~N}_{3} \mathrm{O}_{6} \mathrm{Si}$ : C, 56.36; H, 6.53; N, 9.39. Found: C, 56.59; H, 6.28; N, 9.49.

\subsection{Spectroscopic studies}

General

The solvents used were of spectroscopic grade and provided by Sigma and Merck. Absorption spectra were recorded on a double beam Varian UV-VIS Cary 300 Scan spectrometer, using $10 \mathrm{~mm}$ pathway quartz cuvettes. The steady-state fluorescence experiments were carried out on a Photon Technology International (PTI) LPS-220B spectrofluorometer. Emission and excitation spectra were 
recorded using $10 \times 10 \mathrm{~mm}^{2}$ quartz cells with $4 \mathrm{~mL}$ capacity, using air-equilibrated solutions. The absorbance was adjusted at the excitation wavelength and kept in the range 0.10-0.15. All the experiments were carried out at room temperature.

\subsection{Steady state photolysis}

Photolysis of $2.7 \times 10^{-4} \mathrm{M}$ of compounds $\mathbf{1}$ and $\mathbf{2}$ were performed to evaluate their photostability in DMSO, EtOH and hexane. Broadband irradiations of the solutions were carried out using an ABET Technology solar simulator with a $200 \mathrm{~W}$ Xe arc. Its output was adequately filtered to produce a spectrum approximating natural sunlight (1.5 G air mass filter). The spectral output was measured as ca $1000 \mathrm{~W} / \mathrm{m}^{2}$. The photostability was evaluated by UV-Vis spectroscopy, recording the changes of the UVA-band.

\section{Conclusions}

In this work, two new 2-(2'-hydroxyaryl)benzotriazoles were considered as potential UV-filters. The typical spectroscopic properties of 2'-hydroxybenzotriazole derivatives were obtained for compound 1, which undergoes a photoinduced excited state intramolecular proton transfer in hexane; conversely the use of more polar solvents like ethanol or DMSO results in the disruption of the intramolecular bond. By contrast, no solvent effect was observed for compound 2. Moreover, steady state photolysis showed that both compounds exhibit a potential applicability as UV filters due to their UVA-absorption capability and to their photostability.

\section{Acknowledgements}

We are grateful to Pal Kolonits and Endre Palosi for the analysis. The financial support for this investigation provided by ISDIN (Barcelona, Spain) is greatly appreciated. Spanish government was acknowledged (Ramon y Cajal contract).

\section{References and Notes}

1. Crawford, J.C. 2(2-Hydroxy-phenyl)2H-benzotriazole ultraviolet stabilizers. Prog. Polym. Sci. 1999, 24, 7-43.

2. Rastogi, S.C. UV filters in sunscreen products - a survey. Contact Dermatitis 2002, 46, 348-351.

3. Antoniou, C.; Kosmadaki, M.G.; Stratigos, A.J.; Katsambas, A.D. Sunscreens - what's important to know. J. Eur. Acad. Dermatol. Venereol. 2008, 22, 1110-1118.

4. Chudoba, C.; Riedle, E.; Pfeiffer, M.; Elsaesser, T. Vibrational coherence in ultrafast excited state proton transfer. Chem. Phys. Lett. 1996, 263, 622-628.

5. Fournier, T.; Pommeret, S.; Mialocq, J.-C.; Deflandre, A.; Rozot, R. Fentosecond laser studies of excited state intramolecular proton transfer in an ultraviolet-filter molecule. Chem. Phys. Lett. 2000, 325, 171-175.

6. Otterstedt, J.-E.A. Photostability and molecular structure. J. Chem. Phys. 1973, 58, 5716-5725. 
7. Woessner, G.; Goeller, G.; Rieker, J.; Hoier, H.; Stezowski, J.J.; Daltrozzo, E.; Neureiter M.; Kramer, H.E.A. Ultraviolet stabilizers of the 2-hydroxyphenylbenzotriazole class - influence of the solvent on the absorption spectra and photochemical deactivation mechanism. J. Phys. Chem. 1985, 89, 3629-3636.

8. Wiechmann, M.; Port, H.; Frey, W.; Larmer, F.; Elsaesser, T. Excited-state proton transfer in a benzotriazole photostabilizer investigated by femtosecond spectroscopy. J. Phys. Chem. 1991, 95, 1918-1923.

9. Huston, A.L.; Scott, G.W. Spectroscopic and kinetic investigations of internally hydrogen-bonded (hydroxyphenyl)benzotriazoles. J. Phys. Chem. 1987, 91, 1408-1413.

10. Rieker, J.; Lemmert-Schmitt, E.; Goeller, G.; Roessler, M.; Stueber, G.J.; Schettler, H.; Kramer, H.E.A.; Stezowski, J.J.; Hoier, H.; Henkel, S.; Schmidt, A.; Port, H.; Wiechmann, M.; Rody, J.; Rytz, G.; Slongo, M.; Birbaum, J.-L. Ultraviolet stabilizers of the 2-(hydroxyphenyl)benzotriazole class: influence of substituents on structure and spectra. J. Phys. Chem. 1992, 96, 10225-10234.

11. Catalan, J.; Perez, P.; Claramunt, R.M.; Santa Maria, D.; Bobosik, V. On the molecular conformation of bisaromatic systems. The case of 2-phenyl-2H-benzotriazole. Chem. Phys. 2007, 340, 32-42.

12. Mc Garry, P.F.; Jockusch, S.; Fujiwara, Y.; Kaprinidis, N.A.; Turro, N.J. DMSO solvent induced photochemistry in highly photostable compounds. The role of intermolecular hydrogen bonding. J. Phys. Chem. A 1997, 101, 764-768.

13. Woessner, G.; Goeller, G.; Kollat, P.; Stezowski, J.J.; Hauser, M.; Klein, U.K.A.; Kramer, H.E.A. Photophysical and photochemical deactivation processes of ultraviolet stabilizers of the (2hydroxyphenyl)benzotriazole class. J. Phys. Chem. 1984, 88, 5544-5550.

14. Gorchs, O.C.; Alonso, O.J.; Trullas, C.; Ramon, R.; Corbera, A.J.; Panyella, C.D.; Novak, L., Silylated, substituted benzotriazolylphenol compounds. PCT Int. Appl. WO 2008131921 A1, 6 November 2008.

15. Karstedt, B.D. $\mathrm{Pt}_{2}$ (divinyltetramethyldisiloxane) ${ }_{3}$. U.S. Patent 3,814,720, 4 June 1974.

16. Hitchcock, P.B.; Lappert, M.F.; Warhurst, N.J. Synthesis and structure of a ractris(divinyldisiloxane) diplatinum(o) complex and its reaction with maleic anhydride. Angew. Chem. Int. Ed. Engl. 1991, 30, 438-440.

17. Dean, N.B.; Whalley, W.B. The pigments of “dragon's blood” resin. Part VI. 3:5dihydroxydiphenyl ether. J. Chem. Soc. 1954, 4638-4641.

Sample Availability: Samples of the compound $\mathbf{1}$ are available from the authors.

(C) 2010 by the authors; licensee MDPI, Basel, Switzerland. This article is an Open Access article distributed under the terms and conditions of the Creative Commons Attribution license (http://creativecommons.org/licenses/by/3.0/). 